\title{
PEMILIHAN TAMAN KANAK-KANAK MENGGUNAKAN METODE WEIGHTED PRODUCT DI KECAMATAN SUNGAI KUNJANG SAMARINDA
}

\author{
Septya Maharani ${ }^{1}$, Shinta Hermawati ${ }^{2}$, Indah Fitri Astuti ${ }^{3}$, Heliza Rahmania Hatta ${ }^{4}$, Dyna \\ Marisa Khairina ${ }^{5}$
}

${ }^{1,2,3)}$ Program Studi Ilmu Komputer,Fakultas Ilmu Komputer dan Teknologi Informasi Universitas Mulawarman Email: septyamaharani@gmail.com ${ }^{1)}$, shintahermawati112@yahoo.com ${ }^{2}$ ), indahfitriastuti@yahoo.com ${ }^{3)}$, heliza.rahmania@gmail.com ${ }^{4)}$,dyna.ilkom@gmail.com ${ }^{5)}$

(Naskah masuk: 22 Mei 2018, diterima untuk diterbitkan: 23 September 2018)

\begin{abstract}
Abstrak
Taman kanak-kanak (TK) yang semakin banyak dan ketatnya persaingan dalam dunia pendidikan untuk menunjukan yang terbaik, membuat para orang tua tergesa-gesa dalam memilih TK tanpa disesuaikan dengan kebutuhan anak dan orang tua. Metode yang digunakan untuk permasalahan pemilihan (TK) ini adalah metode Weighted Product (WP) dimana rating setiap atribut harus dipangkatkan dulu dengan bobot atribut yang bersangkutan untuk menentukan solusi alternatif terbaik. Sistem ini dapat memberikan rekomendasi TK yang sesuai dengan harapan orang tua untuk menjadi pertimbangan dalam memilih TK yang tepat, khususnya di Kecamatan Sungai Kunjang, Samarinda yang terdapat 28 TK. Telah dihasilkan Sistem Pendukung Keputusan Pemilihan Taman Kanak-Kanak dengan menggunakan kriteria: lokasi, biaya SPP, biaya masuk, fasilitas, batas tampung kelas, jumlah pengajar, akreditasi TK, status TK, dan menerima anak berkebutuhan khusus. Telah dilakukan perhitungan metode Weighted Product (WP) dengan pengujian perbandingan perhitungan manual dan sistem dan memiliki nilai yang sama. Dalam penelitian ini tingkat akurasi tidak dilakukan, disebabkan peneliti hanya melakukan perangkingan terhadap beberapa TK di Kecamtan Sungai Kunjang, dan hasil dari penelitian merupakan dari salah satu orang tua atau user sebagai pengguna, dimana hasilnya didapatkan bahwa diperolah nilai perangkingan teringgi adalah TK $\left(\mathrm{A}_{14}\right)$ dengan nilai 0.0438 .
\end{abstract}

Kata kunci: Pemilihan Taman Kanak-Kanak (TK), Sistem Pendukung Keputusan, Weighted Product (WP)

\section{A SELECTION OF KINDERGARTEN USING WEIGHTED PRODUCT METHOD IN THE SUBDISTRICT OF SUNGAI KUNJANG SAMARINDA}

\begin{abstract}
Number of kindergartens and tight competition in the education world to show the best, makes the parents hasty in choosing a kindergarten without being tailored to the needs of children and parents. The method used for this kindergarten selection problem is the Weighted Product (WP) where the rating of each attribute must be raised first with the corresponding attribute weights to determine the best alternative solution. This system can provide recommendation of kindergarten in accordance with the expectations of parents to be considered in choosing the right schools, especially in Sungai Kunjang subdistrict, Samarinda, which has 28 kindergartens. A selection of Kindergarten Decision Support System has been generated using criteria: location, tuition fee, entrance fee, facilities, class limit, number of teachers, kindergarten accreditation, kindergarten status and receiving special needs children. The weight product method has been calculated by comparing comparisons and has the same value. In this study the level of accuracy was not carried out, because researchers only carried out ranking against several kindergarten in Sungai Kunjang District, and the results of the study were from one parent or user as a user, where the results were obtained that the highest ranking was TK (A14) with value of 0.0438.
\end{abstract}

Keywords: Selection of Kindergarten, Decision Support System, Weighted Product (WP) 


\section{PENDAHULUAN}

Pendidikan anak usia dini (PAUD) adalah jenjang pendidikan sebelum jenjang pendidikan dasar yang merupakan suatu upaya pembinaan yang ditujukan bagi anak sejak lahir sampai dengan usia enam tahun. (Hasan, 2011). Memilih sekolah yang tepat merupakan hal yang sangat penting dalam hidup, karena sekolah yang dipilih akan mempengaruhi pendidikan dan masa depan. (Firdausa, 2016)

Namun dalam memilih TK tidaklah semudah yang dibayangkan, banyak faktor yang dipertimbangkan oleh orang tua sebelum memutuskan untuk memilih sekolah, dengan banyaknya pertimbangan membuat orang tua harus lebih bijak dalam menentukan TK mana yang tepat untuk menyekolahkan anak mereka. Pada kecamatan Sungai Kunjang terdapat 64 pendidikan anak usia dini (PAUD), diantaranya terdapat 28 taman kanakkanak (TK). Maka sangat diperlukan aplikasi menggunakan sistem penunjang keputusan (SPK) dalam mempermudah orang tua dalam memilih TK yang sesuai. SPK adalah sebuah sistem untuk memberikan kemudahan pengguna dalam mengambil keputusan dari berbagai jenis dengan akurat dan seusai dengan tujuan pengguna (Faisal, 2015).

Beberapa penelitian mengenai pemilihan murid terbaik taman kanak-kanak dengan menggunakan metode Simple Additive Weight (SAW) telah memiliki tingkat dengan menguji 30 anak Taman Kanak-Kanak, mendapatkan Akurasi 20\% (Dedy dkk, 2015). Penelitian berikutnya implementasi metode Weighted Product (WP) untuk aplikasi pemilihan pemilihan Smartphone Android dengan mengambil nilai $V$ yang tertinggi untuk memberi rekomendasi smartphone, menghasilkan nilai vektor teritinggi untuk jenis HP (Khairina, 2016). Metode weight product juga dapat pemilihan lokasi lahan baru pemakaman muslim dengan menggunakan Visual Google Maps. Tujuan penelitian ini memudahkan pemerintah untuk mendapatkan lahan baru sesuai kriteria yang berkaitan dengan pemerintah (Hatta, 2016). Perbedaan penelitianpenelitian di atas adalah penggunaan kriteria berdasarkan kasus penelitian. Peneliti belum menemukan untuk metode weight product belum digunakan untuk pemilihan Taman Kanak - Kanak.

Berdasarkan latar belakang yang telah diuraikan, maka diadakan penelitian Sistem Pendukung Keputusan Pemilihan Taman KanakKanak Menggunakan Metode Weighted Product. Yang diharapkan dapat memberikan rekomendasi TK yang ideal kepada orang tua untuk menjadi pertimbangan dalam memilih sekolah yang tepat untuk anak mereka, khususnya masyarakat Kecamatan Sungai Kunjang, Samarinda.

\section{METODE PENELITIAN}

Taman kanak-kanak (TK) adalah bentuk satuan PAUD pada jalur pendidikan formal yang menyelenggarakan program pendidikan bagi anak berusia 4 tahun sampai 6 tahun dengan prioritas usia dari 5 tahun sampai 6 tahun. Kurikulum TK ditekankan pada pemberian rangsangan pendidikan untuk membantu pertumbuhan dan perkembangan jasmani dan rohani agar anak memiliki kesiapan dalam memasuki pendidikan lebih lanjut (Luthfi, 2014).

Tujuan TK adalah meningkatkan daya cipta anak-anak dan memacu mereka untuk belajar mengenal berbagai macam ilmu pengetahuan melalui pendekatan nilai budi bahasa, agama, sosial, emosional, fisik, motorik, kognitif, bahasa, seni, dan kemandirian. Semua dirancang sebagai upaya mengembangkan daya pikir dan peranan anak dalam hidupnya. kegiatan belajar ini dibuat dalam model belajar sambil bermain.

\subsection{Metode Weighted Product (WP)}

Metode weighted product merupakan metode untuk menyelesaikan Multi Attribute Decision Making (MADM). Weighted Product menggunakan teknik perkalian untuk menghubungkan rating attribute, dimana rating tiap atribut harus dipangkatkan terlebih dahulu dengan atribut bobot yang bersangkutan (Kusumadewi, 2006). Langkahlangkah yang dilakukan dalam penyelesaian masalah menggunakan metode Weighted Product adalah.

1. Normalisasi atau Perbaikan Bobot $W_{j}=\frac{W_{j}}{\sum W_{j}}$

Melakukan normalisasi atau perbaikan bobot untuk menghasilkan nilai $\mathrm{W}_{\mathrm{j}}=1$, dimana $j=1,2, \ldots, \mathrm{n}$ adalah banyak alternatif dan $\sum \mathrm{W}_{\mathrm{j}}$ adalah jumlah keseluruhan nilai bobot.

\section{Menentukan Nilai Vektor S}

$\mathrm{S}_{\mathrm{i}}=\prod_{j=1}^{n} x_{i j}{ }^{w j}$

Menentukan nilai vektor S dengan cara mengalikan seluruh kriteria dengan alternatif hasil normalisasi atau perbaikan bobot yang berpangkat positif untuk kriteria keuntungan (benefit) dan yang berpangkat negatif untuk kriteria biaya (cost). Dimana S merupakan preferensi kriteria, $x$ merupakan nilai kriteria dan $n$ merupakan banyaknya kriteria.

\section{Menentukan Nilai Vektor V}

$$
\mathrm{V}_{\mathrm{i}}=\frac{\prod_{j=1}^{n} x_{i j}{ }^{w j}}{\prod_{j=1}^{n}\left(x_{j}^{w}\right)^{w j}}
$$

Menentukan nilai vektor $\mathrm{V}$ dimana vektor $\mathrm{V}$ merupakan prefernsi alternatif yang akan digunakan untuk perankingan dari masing-masing jumlah nilai vektor $\mathrm{S}$ dengan jumlah seluruh nilai vektor $\mathrm{S}$. 


\subsection{Alur Sistem}

Alur sistem Gambar 1 menjelaskan pengguna memasukan kriteria TK yang diinginkan. Data Kriteria dikonversi dengan bobot data kriteria TK. Hasil konversi merupakan Matriks Keputusan, selanjutnya melakukan normalisai bobot. Setelah itu menghitung nilai Vektor $S$ dan menghitung nilai Vektor $V$, sehingga menghasilkan rekomendasi TK.

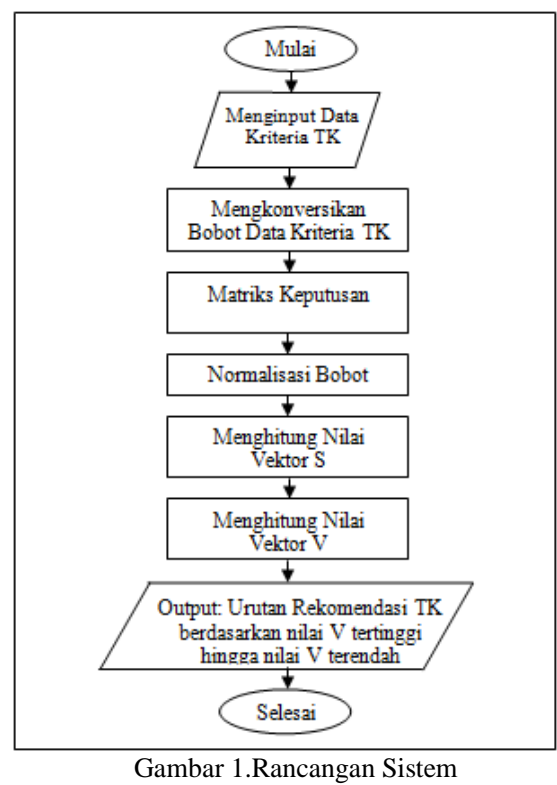

\subsection{Analisis Data}

Analisis data hasil pemilihan yang dibutuhkan dalam menentukan input-an pada sistem agar memudahkan dalam perhitungan nantinya. Analisis data memberikan keterangan kriteria sebagai bahan untuk penyeleksian. Kriteria didapatkan dari pembagian kuesioner. Kuesioner dibagikan kepada orang tua sebagai responden dengan jumlah 90 responden di Taman kanak-kanak di wilayah kecamatan Sungai Kunjang. Kemudian dari kuesioner tersebut dihasilkan beberapa kriteria yang akan digunakan yaitu lokasi, biaya SPP, biaya masuk, fasilitas, batas tampung kelas, jumlah pengajar, akreditasi TK, status TK, dan menerima anak berkebutuhan khusus (ABK).

Berikut merupakan Tabel 1 yang menyajukan parameter nilai bobot kriteria pemilihan Taman kanak-kanak di kecamatan Sungai Kunjang, Samarinda yakni:

\begin{tabular}{llc}
\multicolumn{2}{c}{ Tabel 1. Tabel Parameter dan Bobot Kriteria } \\
\hline \multicolumn{1}{c}{ Kriteria } & \multicolumn{1}{c}{ Parameter } & Bobot \\
\hline Lokasi* & Satu Kelurahan & 3 \\
& Kelurahan Terdekat & 2 \\
& Kelurahan Terjauh & 1 \\
\hline Biaya SPP & < Rp. 100.000 & 3 \\
& $>$ Rp. $100.000-\leq$ Rp. 185.000 & 2 \\
& $>$ Rp. 185.000 & 1 \\
\hline Biaya Masuk & $\leq$ Rp. 1.250 .000 & 3 \\
& $>$ Rp. $1.250 .000-\leq$ Rp. & 2 \\
& 2.000.000 & \\
& $>$ Rp. 2.000 .000 & 1 \\
\hline
\end{tabular}

\begin{tabular}{lll}
\hline Fasilitas* & $>8$ & 3 \\
& $>4-\leq 8$ & 2 \\
& $\leq 4$ & 1 \\
\hline Batas & $\leq 15$ siswa & 3 \\
Tampung & $>15-\leq 22$ siswa & 2 \\
Kelas & $>22$ siswa & 1 \\
\hline Jumlah & 3 pengajar & 3 \\
Pengajar & 2 pengajar & 2 \\
Perkelas & 3 pengajar & 1 \\
\hline Akreditasi TK & A & 3 \\
& B & 2 \\
& Belum Terakreditasi & 1 \\
\hline Status TK & Swasta & 2 \\
& Negeri & 1 \\
\hline Menerima & Iya & 2 \\
Anak & Tidak & 1 \\
Berkebutuhan & & \\
Khusus (ABK) & & \\
\hline
\end{tabular}

Keterangan kriteria:

*Fasilitas: Jika terdapat beberapa fasilitas berikut.

1. Ruang Kepala Sekolah 8. Perpustakaan

2. Ruang Guru 9. Gudang

3. Ruang Kelas 10. Dapur

4. Toilet 11. Ruang Administrasi

5. Taman Bermain 12. Kantin

6. Ruang UKS 13. Kebun

7. Aula

\section{HASIL DAN PEMBAHASAN}

3.1. Activity Diagram

Activity Diagram menjelaskan mengenai alur-alur kegiatan yang dilakukan oleh pengguna terhadap sistem. Bagaimana masing-masing alur berawal, decision yang mungkin terjadi, dan bagaimana masing-masing alur berakhir. Gambar 2 memperlihatkan activity diagram saat aplikasi pertama kali diakses, dimana halaman default yang muncul adalah halaman utama. Selanjutnya pengguna dapat mengakses data TK, SPK pemilihan TK, dan langkah penggunaan aplikasi. Pada halaman langkah penggunaan aplikasi, pengguna dapat terlebih dahulu membaca bagaimana langkah penggunaan aplikasi. Pada halaman data TK, pengguna dapat melihat data TK yang berada di Kecamatan Sungai Kunjang, Samarinda. Namun pilihan ubah data hanya dapat dilakukan oleh admin yang berhasil masuk dengan kata sandi. Kembali pada halaman utama, ketika pengguna mengakses SPK pemilihan TK, pengguna dapat mengisi kriteria TK yang diharapkan, setelah bobot dari kriteria tersebut telah dikonversikan, perhitungan akan diproses menggunakan metode WP, kemudian akan muncul hasil urutan rekomendasi TK sesuai kebutuhan yang diharapkan oleh pengguna tersebut. 


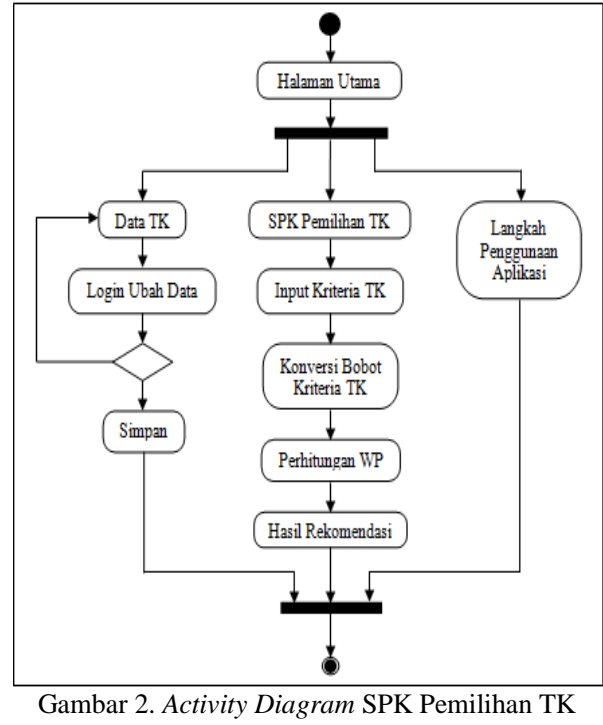

\subsection{Implemenatsi Sistem}

Implementasi merupakan proses realisasi pembuatan sistem dari aplikasi berdasarkan perancangan-perancangan yang telah dilakukan. Implementasi ini menghasilkan sebuah aplikasi yang memiliki beberapa halaman/form dan dapat diakses oleh pengguna.

Saat aplikasi pertama kali diakses, dimana halaman default yang muncul adalah halaman utama. Tampilan interface dari halaman utama ditunjukkan pada Gambar 3.

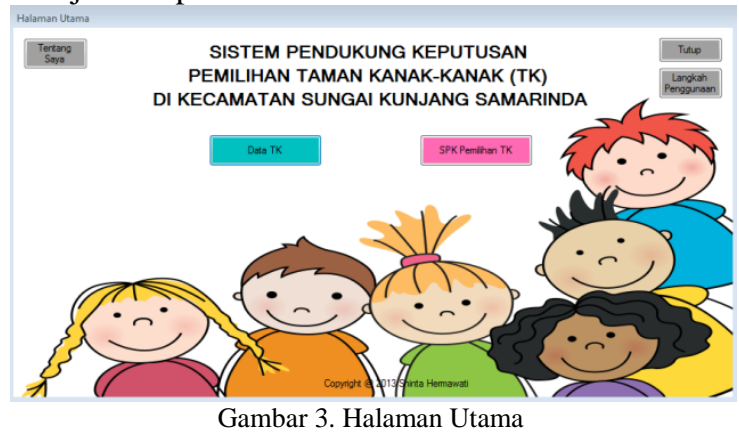

Pada halaman utama terdapat beberapa tombol diantaranya tombol Data TK, SPK Pemilihan TK, Langkah Penggunaan, dan tombol Tutup. Kemudian kembali pada halaman utama, halaman data TK adalah halaman yang akan muncul jika pengguna memilih menu Data TK. Tampilan interface dari halaman data TK dapat dilihat pada Gambar 4. Pada halaman ini pengguna dapat melihat data TK yang berada di Kecamatan Sungai Kunjang, seperti alamat, biaya SPP, biaya masuk, batas tampung kelas, jumlah pengajar perkelas, akreditasi, status, menerima anak berkebutuhan khusus, dan jumlah fasilitas tiap TK. Untuk mengubah dan menyimpan perubahan hanya dapat dilakukan oleh admin yang telah melalukan login terlebih dahulu.

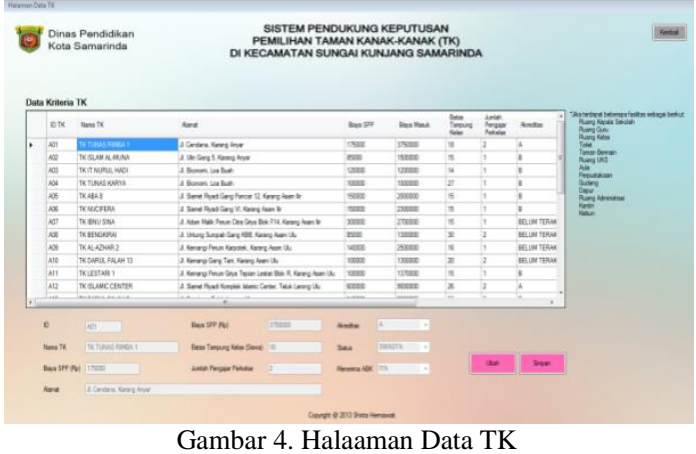

Kembali pada menu yang terdapat pada halaman utama, terdapat menu SPK Pemilihan TK dimana pengguna dapat memasukkan lokasi kecamatan pengguna dan kriteria sesuai harapan pengguna seperti biaya spp, biaya masuk, batas tampung kelas, jumlah pengajar perkelas, akreditasi TK, status TK, menerima anak berkebutuhan khusus (ABK), dan jumlah fasilitas. Tampilan dari halaman ini dapat dilihat pada Gambar 5.

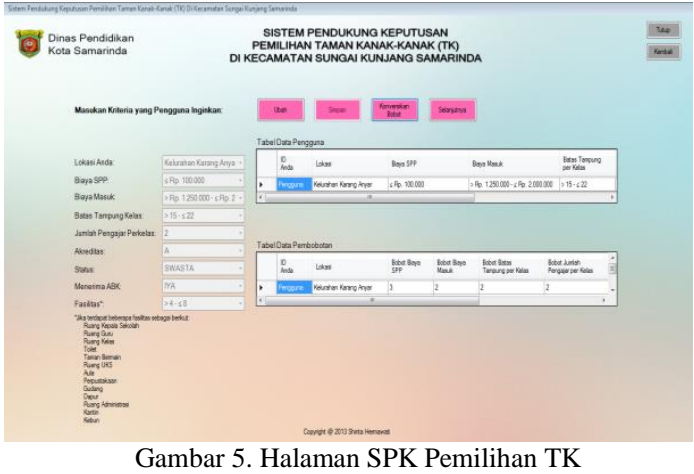

Setelah pengguna telah menginput data pada halaman pemilihan, selanjutnya akan menampilkan halaman hasil dan rekomendasi TK. Pada halaman ini menampilkan hasil rekomendasi berdasarkan kriteria harapan pengguna dengan menggunakan metode Weighted Product (WP). Pengguna dapat melihat proses perhitungan secara detail dengan mengklik tombol Perhitungan Detail yang terdapat pada halaman ini. Tampilan dari halaman ini dapat dilihat pada Gambar 6.

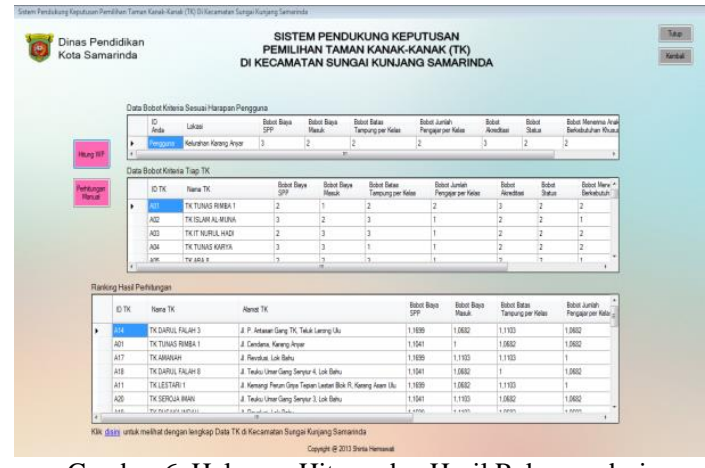

Gambar 6. Halaman Hitung dan Hasil Rekomendasi 


\subsection{Pengujian Sistem}

Uji coba dilakukan untuk mengetahui apakah aplikasi yang dibuat sesuai dengan tujuan. Uji coba dilakukan dengan menggunakan perhitungan manual. Dilakukan uji coba terhadap satu data sampel yang akan dihitung dengan 28 data TK di Kecamatan Sungai Kunjang Samarinda untuk mendapatkan alternatif terbaik. Tabel 2 menyajikan data yang akan diuji dengan perhitungan manual.

\begin{tabular}{ll}
\multicolumn{2}{c}{ Tabel 2. Pengujian Data } \\
\hline Kriteria & Kriteria dari Pengguna \\
\hline Lokasi & Kelurahan Karang Anyar \\
Biaya SPP & $\leq$ Rp. 100.000 \\
Biaya Masuk & $>$ Rp. $1.250 .000-\leq$ Rp. \\
& 2.000 .000 \\
Batas Tampung Kelas & $>15-\leq 22$ \\
Jumlah Pengajar Perkelas & 2 \\
Akreditasi & A \\
Status & SWASTA \\
Menerima ABK & IYA \\
Jumlah Fasilitas & $>4-\leq 8$ \\
\hline
\end{tabular}

Data kriteria dari pengguna pada Tabel 2 kemudian dikonversikan dalam bentuk bobot preferensi. Lokasi Kelurahan Karang Anyar pada bobot preferensi bernilai 3, biaya SPP $\leq$ Rp. 100.000 pada bobot preferensi bernilai 3, biaya masuk > Rp. $1.250 .000-\leq$ Rp. 2.000 .000 pada bobot preferensi bernilai 2, batas tampung kelas $>15-\leq 22$ siswa pada bobot preferensi bernilai 2, jumlah pengajar perkelas 2 orang pada bobot preferensi bernilai 2, terakreditasi A pada bobot preferensi bernilai 3, status swasta pada bobot preferensi bernilai 2, menerima ABK pada bobot preferensi berniai 2, dan jumlah fasilitas $>4-\leq 8$ pada bobot preferensi bernilai 2 . Kemudian didapatkan rating kecocokan seperti pada Tabel 3 .

\section{Rating Kecocokan}

\begin{tabular}{|c|c|c|c|c|c|c|c|c|c|}
\hline \multirow{2}{*}{$\begin{array}{l}\text { Alter- } \\
\text { natif }\end{array}$} & \multicolumn{9}{|c|}{ Kriteria } \\
\hline & C1 & C2 & C3 & C4 & C5 & C6 & C7 & C8 & C9 \\
\hline A01 & 2 & 1 & 2 & 2 & 3 & 2 & 2 & 3 & 3 \\
\hline A02 & 3 & 2 & 3 & 1 & 2 & 2 & 1 & 1 & 3 \\
\hline A03 & 2 & 3 & 3 & 1 & 2 & 2 & 2 & 2 & 1 \\
\hline A04 & 3 & 3 & 1 & 1 & 2 & 2 & 2 & 2 & 1 \\
\hline A05 & 2 & 2 & 3 & 1 & 2 & 2 & 1 & 3 & 2 \\
\hline A06 & 2 & 1 & 3 & 1 & 2 & 2 & 1 & 3 & 2 \\
\hline A07 & 1 & 1 & 3 & 1 & 1 & 2 & 2 & 3 & 2 \\
\hline A08 & 3 & 2 & 1 & 2 & 1 & 2 & 1 & 2 & 2 \\
\hline A09 & 2 & 1 & 2 & 1 & 1 & 2 & 1 & 1 & 2 \\
\hline A10 & 3 & 2 & 2 & 2 & 1 & 2 & 2 & 2 & 2 \\
\hline A11 & 3 & 2 & 3 & 1 & 2 & 2 & 1 & 2 & 2 \\
\hline A12 & 1 & 1 & 1 & 2 & 3 & 2 & 1 & 3 & 2 \\
\hline A13 & 2 & 1 & 1 & 2 & 2 & 2 & 2 & 2 & 2 \\
\hline A14 & 3 & 2 & 3 & 2 & 2 & 2 & 2 & 2 & 2 \\
\hline
\end{tabular}

\begin{tabular}{|l|l|l|l|l|l|l|l|l|l|}
\hline $\mathrm{A} 15$ & 2 & 2 & 1 & 2 & 2 & 2 & 2 & 2 & 2 \\
\hline $\mathrm{A} 16$ & 2 & 1 & 3 & 2 & 1 & 2 & 1 & 2 & 2 \\
\hline $\mathrm{A} 17$ & 3 & 3 & 3 & 1 & 2 & 2 & 2 & 2 & 2 \\
\hline $\mathrm{A} 18$ & 2 & 2 & 1 & 2 & 2 & 2 & 2 & 3 & 2 \\
\hline $\mathrm{A} 19$ & 3 & 3 & 2 & 2 & 2 & 2 & 1 & 1 & 2 \\
\hline $\mathrm{A} 20$ & 2 & 3 & 2 & 2 & 3 & 2 & 1 & 1 & 2 \\
\hline $\mathrm{A} 21$ & 1 & 1 & 1 & 3 & 1 & 2 & 2 & 3 & 1 \\
\hline $\mathrm{A} 22$ & 2 & 3 & 2 & 2 & 2 & 2 & 2 & 2 & 1 \\
\hline $\mathrm{A} 23$ & 2 & 2 & 3 & 1 & 1 & 2 & 2 & 2 & 1 \\
\hline $\mathrm{A} 24$ & 2 & 1 & 1 & 2 & 1 & 2 & 1 & 2 & 1 \\
\hline $\mathrm{A} 25$ & 2 & 2 & 1 & 2 & 3 & 1 & 2 & 3 & 1 \\
\hline $\mathrm{A} 26$ & 3 & 3 & 2 & 1 & 2 & 2 & 1 & 2 & 1 \\
\hline $\mathrm{A} 27$ & 2 & 2 & 3 & 1 & 2 & 2 & 2 & 2 & 1 \\
\hline $\mathrm{A} 28$ & 2 & 2 & 2 & 2 & 3 & 2 & 2 & 2 & 1 \\
\hline
\end{tabular}

Keterangan:

C1: Biaya SPP

C2: Biaya Masuk

C3: Batas Tampung Kelas

C4:Jumlah Pengajar Kelas

C5: Akreditasi TK

C6: Status TK

C7: Menerima ABK

C8: Jumlah Fasilitas

C9: Lokasi

Berdasarkan Tabel rating kecocokan tersebut, berikut adalah matriks $\mathrm{X}$ pada perhitungan metode WP di sistem, seperti yang dapat dilihat pada Gambar 7.

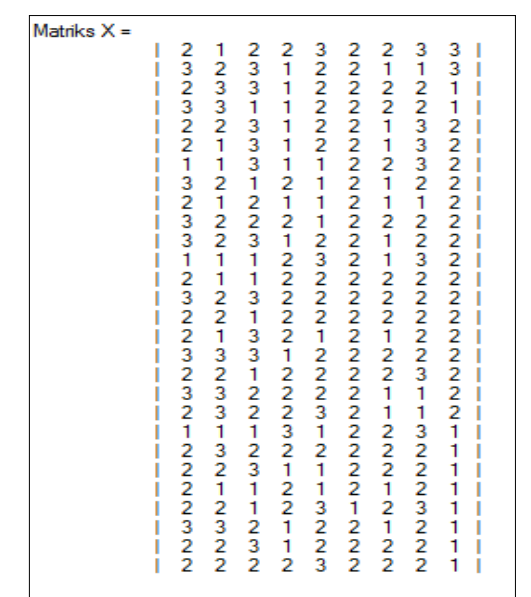

Gambar 7. Matriks X pada Perhitungan Detail Sistem

\section{Normalisasi Bobot}

Sebelumnya akan dilakukan perbaikan bobot terlebih dahulu. Bobot awal $\mathrm{W}=(3,2,2,2,3,2,2$, 2, 3), akan diperbaiki sehingga total bobot $\sum \mathrm{Wj}=1$, dengan persamaan (1). Berikut adalah perbaikan atau normalisasi bobot pada perhitungan metode WP di sistem, seperti yang dapat dilihat pada Gambar 8 . 
$w 1=3 /(3+2+2+2+3+2+2+2+3)=0.1429$

$w 2=2 /(3+2+2+2+3+2+2+2+3)=0,0952$

$w 3=2 /(3+2+2+2+3+2+2+2+3)=0.0952$

$w 4=2 /(3+2+2+2+3+2+2+2+3)=0.0952$

$w 5=3 /(3+2+2+2+3+2+2+2+3)=0.1429$

$w 6=2 /(3+2+2+2+3+2+2+2+3)=0.0952$

$w 7=2 /(3+2+2+2+3+2+2+2+3)=0.0952$

$w 8=2 /(3+2+2+2+3+2+2+2+3)=0.0952$

$w 9=3 /(3+2+2+2+3+2+2+2+3)=0.1429$

Gambar 8. Normalisasi Bobot pada Perhitungan Detail Sistem

3. Menghitung nilai vektor $\mathrm{S}$

Kemudian vektor $\mathrm{S}$ dihitung berdasarkan persamaan (2) sehingga mendapatkan hasil seperti pada Tabel 4.

Tabel 4. Hasil Perhitungan Nilai S

\begin{tabular}{|c|c|}
\hline Alternatif TK & Nilai $\mathbf{S}$ \\
\hline A01 & 2,185 \\
\hline A02 & 1,9147 \\
\hline A03 & 1,8319 \\
\hline A04 & 1,7483 \\
\hline A05 & 1,8934 \\
\hline A06 & 1,7724 \\
\hline A07 & 1,5532 \\
\hline A08 & 1,6821 \\
\hline A09 & 1,3911 \\
\hline A10 & 1,9195 \\
\hline A11 & 1,9303 \\
\hline A12 & 1,6366 \\
\hline A13 & 1,7526 \\
\hline A14 & 2,2027 \\
\hline A15 & 1,8722 \\
\hline A16 & 1,6499 \\
\hline A17 & 2,1432 \\
\hline A18 & 1,9459 \\
\hline A19 & 1,9303 \\
\hline A 20 & 1,9303 \\
\hline $\mathrm{A} 21$ & 1,4068 \\
\hline A22 & 1,8828 \\
\hline A 23 & 1,5963 \\
\hline A 24 & 1,3459 \\
\hline A25 & 1,7483 \\
\hline A26 & 1,7483 \\
\hline A27 & 1,7625 \\
\hline A28 & 1,9195 \\
\hline Total Nilai S & 50,296 \\
\hline
\end{tabular}

Berdasarkan Tabel perhitungan nilai vektor $\mathrm{S}$ diatas, berikut adalah perhitungan nilai vektor $S$ pada perhitungan metode WP di sistem, seperti yang dapat dilihat pada Gambar 9.
Penhitungan Nilai S

TK TUNAS RIMBA $1=\left(2^{\wedge} 0,1429\right)\left(1^{\wedge} 0,0952\right)\left(2^{\wedge} 0,0952\right)\left(2^{\wedge} 0,0952\right)\left(3^{\wedge} 0,1429\right)\left(2^{\wedge} 0,0952\right)\left(2^{\wedge} 0,0952\right)\left(3^{\wedge} 0,0952\right)\left(3^{\wedge} 0,1429\right.$ TK TUNAS RIMBA $1=2,185$

TKISLAM AL-MUNA $=\left(3^{\wedge} 0,1429\right)\left(2^{\wedge} 0,0952\right)\left(3^{\wedge} 0,0952\right)\left(1^{\wedge} 0,0952\right)\left(2^{\wedge} 0,1429\right)\left(2^{\wedge} 0,0952\right)\left(1^{\wedge} 0,0952\right)\left(1^{\wedge} 0,0952\right)\left(3^{\wedge} 0,1429\right)$ TKISLAM AL-MUNA $=1,9147$

TKIT NURUL HADI $=\left(2^{\wedge} 0,1429\right)\left(3^{\wedge} 0,0952\right)\left(3^{\wedge} 0,0952\right)\left(1^{\wedge} 0,0952\right)\left(2^{\wedge} 0,1429\right)\left(2^{\wedge} 0,0952\right)\left(2^{\wedge} 0,0952\right)\left(2^{\wedge} 0,0952\right)\left(1^{\wedge} 0,1429\right)$ TKIT NURUL HADI $=1,8319$

TK TUNAS KARYA $=\left(3^{\wedge} 0,1429\right)\left(3^{\wedge} 0,0952\right)\left(1^{\wedge} 0,0952\right)\left(1^{\wedge} 0,0952\right)\left(2^{\wedge} 0,1429\right)\left(2^{\wedge} 0,0952\right)\left(2^{\wedge} 0,0952\right)\left(2^{\wedge} 0,0952\right)\left(1^{\wedge} 0,1429\right)$ TK TUNAS KARYA $=1,7483$

TKABA $8=\left(2^{\wedge} 0,1429\right)\left(2^{\wedge} 0,0952\right)\left(3^{\wedge} 0,0952\right)\left(1^{\wedge} 0,0952\right)\left(2^{\wedge} 0,1429\right)\left(2^{\wedge} 0,0952\right)\left(1^{\wedge} 0,0952\right)\left(3^{\wedge} 0,0952\right)\left(2^{\wedge} 0,1429\right)$ TKABA $8=1,893$

TK NUCIFERA $=\left(2^{\wedge} 0,1429\right)\left(1^{\wedge} 0,0952\right)\left(3^{\wedge} 0,0952\right)\left(1^{\wedge} 0,0952\right)\left(2^{\wedge} 0,1429\right)\left(2^{\wedge} 0,0952\right)\left(1^{\wedge} 0,0952\right)\left(3^{\wedge} 0,0952\right)\left(2^{\wedge} 0,1429\right)$

TKNUCIFERA $=1,772$

TKIBNU SINA $=\left(1^{\wedge} 0,1429\right)\left(1^{\wedge} 0,0952\right)\left(3^{\wedge} 0,0952\right)\left(1^{\wedge} 0,0952\right)\left(1^{\wedge} 0,1429\right)\left(2^{\wedge} 0,0952\right)\left(2^{\wedge} 0,0952\right)\left(3^{\wedge} 0,0952\right)\left(2^{\wedge} 0,1429\right)$ TKIBNU SINA $=1,5532$

TKBENGKIRAI $=\left(3^{\wedge} 0,1429\right)\left(2^{\wedge} 0,0952\right)\left(\left(^{\wedge} 0,0952\right)\left(2^{\wedge} 0,0952\right)\left(1^{\wedge} 0,1429\right)\left(2^{\wedge} 0,0952\right)\left(1^{\wedge} 0,0952\right)\left(2^{\wedge} 0,0952\right)\left(2^{\wedge} 0,1429\right)\right.$ TKBENGKIRA $=1,682$

TKAL-AZHAR $2=\left(2^{\wedge} 0,1429\right)\left(1^{\wedge} 0,0952\right)\left(2^{\wedge} 0,0952\right)\left(1^{\wedge} 0,0952\right)\left(1^{\wedge} 0,1429\right)\left(2^{\wedge} 0,0952\right)\left(1^{\wedge} 0,0952\right)\left(1^{\wedge} 0,0952\right)\left(2^{\wedge} 0,1429\right)$ TKAL-AZHAR $2=1,3911$

TK DARUL FALAH $13=\left(3^{\wedge} 0,1429\right)\left(2^{\wedge} 0,0952\right)\left(2^{\wedge} 0,0952\right)\left(2^{\wedge} 0,0952\right)\left(1^{\wedge} 0,1429\right)\left(2^{\wedge} 0,0952\right)\left(2^{\wedge} 0,0952\right)\left(2^{\wedge} 0,0952\right)\left(2^{\wedge} 0,1429\right)$ TKDARUL FALAH $13=1,9195$

TKLESTARI $1=\left(3^{\wedge} 0,1429\right)\left(2^{\wedge} 0,0952\right)\left(3^{\wedge} 0,0952\right)\left(1^{\wedge} 0,0952\right)\left(2^{\wedge} 0,1429\right)\left(2^{\wedge} 0,0952\right)\left(1^{\wedge} 0,0952\right)\left(2^{\wedge} 0,0952\right)\left(2^{\wedge} 0,1429\right)$ TKLESTARI $1=1,9303$

TKISLAMIC CENTER $=\left(1^{\wedge} 0,1429\right)\left(1^{\wedge} 0,0952\right)\left(1^{\wedge} 0,0952\right)\left(2^{\wedge} 0,0952\right)\left(3^{\wedge} 0,1429\right)\left(2^{\wedge} 0,0952\right)\left(1^{\wedge} 0,0952\right)\left(3^{\wedge} 0,0952\right)\left(2^{\wedge} 0,1429\right)$ TKISLAMIC CENTER $=1,6366$

TKDARUL FALAH $2=\left(2^{\wedge} 0,1429\right)\left(1^{\wedge} 0,0952\right)\left(1^{\wedge} 0,0952\right)\left(2^{\wedge} 0,0952\right)\left(2^{\wedge} 0,1429\right)\left(2^{\wedge} 0,0952\right)\left(2^{\wedge} 0,0952\right)\left(2^{\wedge} 0,0952\right)\left(2^{\wedge} 0,1429\right)$ TKDARUL FALAH $2=1,7526$

TKDARUL FALAH $3=\left(3^{\wedge} 0,1429\right)\left(2^{\wedge} 0,0952\right)\left(3^{\wedge} 0,0952\right)\left(2^{\wedge} 0,0952\right)\left(2^{\wedge} 0,1429\right)\left(2^{\wedge} 0,0952\right)\left(2^{\wedge} 0,0952\right)\left(2^{\wedge} 0,0952\right)\left(2^{\wedge} 0,1429\right)$ TKDARULFALAH $3=22027$

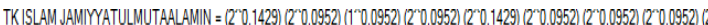
TKISLAM JAMIYYATULMUTALLAMIN $=1,8722$

TKAL-AZHAR $4=\left(2^{\wedge}, 1429\right)\left(1^{\wedge} 0,0952\right)\left(3^{\wedge} 0,0952\right)\left(2^{\wedge} 0,0952\right)\left(1^{\wedge} 0,1429\right)\left(2^{\wedge} 0,0952\right)\left(1^{\wedge} 0,0952\right)\left(2^{\wedge} 0,0952\right)\left(2^{\wedge} 0,1429\right)$ TKAL.AZHAR $4=1,6499$

TKAMANAH $=\left(3^{\wedge} 0,1429\right)\left(3^{\wedge} 0,0952\right)\left(3^{\wedge} 0,0952\right)\left(1^{\wedge} 0,0952\right)\left(2^{\wedge} 0,1429\right)\left(2^{\wedge} 0,0952\right)\left(2^{\wedge} 0,0952\right)\left(2^{\wedge} 0,0952\right)\left(2^{\wedge}, 1429\right.$ TKAMANAH $=2,1432$

TKDARUL FALAH $8=\left(2^{\wedge} 0.1429\right)\left(2^{\wedge} 0,0952\right)\left(1^{\wedge} 0,0952\right)\left(2^{\wedge} 0.0952\right)\left(2^{\wedge} 0,1429\right)\left(2^{\wedge} 0,0952\right)\left(2^{\wedge} 0.0952\right)\left(3^{\wedge} 0.0952\right)\left(2^{\wedge} 0,1429\right)$ TKDARUL FALAH $8=1,9459$

TK PUSAKA INDAH $=\left(3^{\wedge} 0,1429\right)\left(3^{\wedge} 0,0952\right)\left(2^{\wedge} 0,0952\right)\left(2^{\wedge} 0,0952\right)\left(2^{\wedge} 0,1429\right)\left(2^{\wedge} 0,0952\right)\left(1^{\wedge} 0,0952\right)\left(1^{\wedge} 0,0952\right)\left(2^{\wedge} 0,1429\right)$ TKPUSAKA INDAH $=1,9303$

TK SEROJA IIMAN $=\left(2^{\wedge} 0,1429\right)\left(3^{\wedge} 0,0952\right)\left(2^{\wedge} 0,0952\right)\left(2^{\wedge} 0,0952\right)\left(3^{\wedge} 0,1429\right)\left(2^{\wedge} 0,0952\right)\left(1^{\wedge} 0,0952\right)\left(1^{\wedge} 0,0952\right)\left(2^{\wedge} 0,1429\right)$ TKSEROJAIMAN $=1,9303$

TKISLAM AL-AZHAR $46=\left(1^{\wedge} 0,1429\right)\left(1^{\wedge} 0,0952\right)\left(\left(1^{\wedge} 0,0952\right)\left(3^{\wedge} 0,0952\right)\left(1^{\wedge} 0,1429\right)\left(2^{\wedge} 0,0952\right)\left(2^{\wedge} 0,0952\right)\left(3^{\wedge} 0,0952\right)\left(1^{\wedge} 0,1429\right)\right.$ TKISLAM AL-AZHAR 46 $=1,4068$

TKQUANTUM FlQRIYAH $=\left(2^{\wedge}, 1429\right)\left(3^{\wedge} 0,0952\right)\left(2^{\wedge} 0,0952\right)\left(2^{\wedge} 0,0952\right)\left(2^{\wedge} 0,1429\right)\left(2^{\wedge} 0,0952\right)\left(2^{\wedge} 0,0952\right)\left(2^{\wedge} 0,0952\right)\left(1^{\wedge} 0,1429\right)$ TKQUANTUM FLRIYAH $=1,8828$

TKUKAN HASUPA $=\left(2^{\wedge} 0,1429\right)\left(2^{\wedge} 0,0952\right)\left(3^{\wedge} 0,0952\right)\left(1^{\wedge} 0,0952\right)\left(1^{\wedge} 0,1429\right)\left(2^{\wedge} 0.0952\right)\left(2^{\wedge} 0,0952\right)\left(2^{\wedge} 0,0952\right)\left(1^{\wedge} 0,1429\right)$ TKUKAN HASUPA $=1,5963$

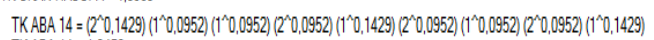
TKABA $14=1,3459$

$\operatorname{TKN} 2=\left(2^{\wedge} 0,1429\right)\left(2^{\wedge} 0,0952\right)\left(1^{\wedge} 0,0952\right)\left(2^{\wedge} 0,0952\right)\left(3^{\wedge} 0,1429\right)\left(1^{\wedge} 0,0952\right)\left(2^{\wedge} 0,0952\right)\left(3^{\wedge} 0,0952\right)\left(1^{\wedge} 0,1429\right)$ TKN $2=1,7483$

TKISLAM AL-AZHAR $=\left(3^{\wedge} 0,1429\right)\left(3^{\wedge} 0,0952\right)\left(2^{\wedge} 0,0952\right)\left(1^{\wedge} 0,0952\right)\left(2^{\wedge} 0,1429\right)\left(2^{\wedge} 0,0952\right)\left(1^{\wedge} 0,0952\right)\left(2^{\wedge} 0,0952\right)\left(1^{\wedge} 0,1429\right)$ TKISLAM AL-AZHAR $=1,7483$

TKISLAM AL-HUSNA $=\left(2^{\wedge} 0,1429\right)\left(2^{\wedge} 0,0952\right)\left(3^{\wedge} 0,0952\right)\left(1^{\wedge} 0,0952\right)\left(2^{\wedge} 0,1429\right)\left(2^{\wedge} 0,0952\right)\left(2^{\wedge} 0,0952\right)\left(2^{\wedge} 0,0952\right)\left(1^{\wedge} 0,1429\right)$ TKISLAM AL HUSNA $=1,7625$

TK TUNAS MULLA $=\left(2^{\wedge} 0,1429\right)\left(2^{\wedge} 0,0952\right)\left(2^{\wedge} 0,0952\right)\left(2^{\wedge} 0,0952\right)\left(3^{\wedge} 0,1429\right)\left(2^{\wedge} 0,0952\right)\left(2^{\wedge} 0,0952\right)\left(2^{\wedge} 0,0952\right)\left(1^{\wedge} 0,1429\right)$ TK TUNAS MULLA $=1,9195$

Gambar 9. Perhitungan Nilai S pada Perhitungan Detail Sistem

\section{Perankingan}

Berdasarkan perhitungan diataas, selanjutnya akan dihasilkan rekomendasi TK di Kecamatan Sungai Kunjang Samarinda dengan urutan nilai V paling besar ke nilai $\mathrm{V}$ paling kecil, dapat dilihat pada Tabel 5. 


\begin{tabular}{|c|c|c|}
\hline Ranking & Alternatif & Nilai V \\
\hline 1 & A14 & 0.0438 \\
\hline 2 & A01 & 0,0434 \\
\hline 3 & A17 & 0,0426 \\
\hline 4 & A18 & 0,0387 \\
\hline 5 & A11 & 0,0384 \\
\hline 6 & A20 & 0,0384 \\
\hline 7 & A19 & 0,0384 \\
\hline 8 & A28 & 0,0382 \\
\hline 9 & A10 & 0,0382 \\
\hline 10 & A02 & 0,0381 \\
\hline 11 & A05 & 0,0376 \\
\hline 12 & A22 & 0,0374 \\
\hline 13 & A15 & 0,0372 \\
\hline 14 & A03 & 0,0364 \\
\hline 15 & A06 & 0,0352 \\
\hline 16 & A27 & 0,035 \\
\hline 17 & A04 & 0,0348 \\
\hline 18 & A13 & 0,0348 \\
\hline 19 & A25 & 0,0348 \\
\hline 20 & A26 & 0,0348 \\
\hline 21 & A08 & 0,0334 \\
\hline 22 & A16 & 0,0328 \\
\hline 23 & A12 & 0,0325 \\
\hline 24 & A23 & 0,0317 \\
\hline 25 & A07 & 0,0309 \\
\hline 26 & A21 & 0,028 \\
\hline 27 & A09 & 0,0277 \\
\hline 28 & A24 & 0,0268 \\
\hline
\end{tabular}

Langkah terakhir adalah proses perankingan. Hasil perankingan diperoleh dengan nilai akhir seperti pada Tabel 5 diatas. Bahwa yg sesuai dengan kebutuhan user diatas ,Maka rekomendasi yang diperoleh dengan Nilai tertinggi dan terbesar ada pada $V_{14}$ dengan nilai $V$ sebesar 0.0438 , sehingga alternatif $\mathrm{A}_{14}$ adalah alternatif yang terpilih sebagai alternatif TK terbaik.

\section{KESIMPULAN}

Dari hasil penelitian yang telah dilakukan, maka dapat disimpulkan bahwa pada metode Weighted Product (WP) mampu menangani masalah pengambilan keputusan pemilihan TK yang dapat memberikan rekomendasi TK yang sesuai dengan harapan orang tua untuk menjadi pertimbangan dalam memilih TK yang tepat, khususnya di
Kecamatan Sungai Kunjang, Samarinda yang terdapat 28 TK. Berdasarkan hasil pengujian sistem perhitungan metode Weighted Product (WP) dengan perhitungan manual, maka didapatkan hasil akhir yang sama dengan perhitungan sistem. Selanjutnya telah dihasilkan nilai perangkingan tertinggi dari salah satu user dalam pemilihan Taman KanakKanak TK $\left(\mathrm{A}_{14}\right)$ dengan nilai 0.0438 ,

\section{DAFTAR PUSTAKA}

FAISAL, 2015. Sistem Penunjang Keputusan Pemilihan Sekolah Menengah Kejuruan Teknik Komputer dan Jaringan Yang Terfavorit Dengan Menggunakan MultiCriteria Decision Making. Jurnal Teknologi Informasi dan Ilmu Komputer (JTIIK). Vol.2 No.1.

FIRDAUSA, 2016. Model Sistem Pendukung Keputusan Pemilihan Sekolah Menggunakan SAW. Seminar Nasional Teknologi Informasi dan Multimedia. Yogyakarta..STMIK AMIKOM.

HASAN, M. 2011. PAUD (Pendidikan Anak Usia Dini). Yogyakarta: Diva Press.

HATTA, H.R., RIZALDI, M. AND KHAIRINA, D.M., 2016. Penerapan Metode Weighted Product Untuk Pemilihan Lokasi Lahan Baru Pemakaman Muslim Dengan Visualisasi Google Maps. Jurnal Teknologi dan Sistem Informasi, 2(3), pp.85-94.

KHAIRINA, D. M., IVANDO, D., \& MAHARANI, S. (2016). Implementasi Metode Weighted Product Untuk Aplikasi Pemilihan Smartphone Android. Jurnal Infotel, 8(1), 16-23.

KUSUMADEWI, S., HARTATI, S., HARJOKO, A. AND WARDOYO, R., 2006. Fuzzy MultiAttribute Decision Making (Fuzzy MADM). Yogyakarta: Graha Ilmu, pp.7879.

LUTHFI, N. 2014. Perancangan Desain Interior Taman Kanak-Kanak Islam. Skripsi S1 Binus.

PRAYOGA, E, D. 2017. Seleksi Murid Terbaik Taman Kanak-Kanak Berbasis Simple Additive Weight. Jurnal PROGRESIF. Vol. 11 No. 2.

SASONGKO, A. ASTUTI, I, F, DAN MAHARANI, S. 2017. Pemilihan Karyawan Baru Dengan Metode AHP (Analytic Hierarchy Process). Jurnal Informatika Mulawarman. Vol. 12 No. 2. 
Halaman ini sengaja dikosongkan 